\title{
DSM Application for Deep Excavation in Singapore
}

\author{
Youn-Chul Chun ${ }^{1 *}$ \\ ${ }^{1}$ Department of Civil Engineering Graduate School of Kyonggi University
}

\section{싱가포르 지역 깊은 굴착을 위한 지반개량공법 DSM의 적용 사례}

\author{
천윤철 ${ }^{*}$ \\ ${ }^{1}$ 경기대학교 대학원 토목공학과
}

\begin{abstract}
DSM (Deep Soil Mixing) is to establish soil-cement column by injecting of cement slurry and blending it in soft ground and have been introduced to Singapore in 1980s and now a days quite popular and considered as alternative method to the jet grouting for temporary earth retaining works and foundations. Herein this paper, the results of lab mixing test based on comparison of characteristics between OPC (Original Portland Cement) and PBFC (Portland Blast Furnace Slag Cement), DSM field trial test and main installation results including monitoring, was presented and it would be referred to similar site later.

요 약 1980년대에 싱가포르에 도입된 심층혼합공법 DSM (Deep Soil Mixing )은 시멘트 슬러리를 지중에 주입시킨 후 이를 원지반 연약토와 교반시킴으로써 견고한 흙-시멘트 기둥을 형성시켜 지반을 보강하는 지반개량공법으로 최근 깊은 굴착을 위한 가설 흙막이 공사에 제트그라우팅의 대안으로 많이 사용되고 있다. 본 논문에서는 OPC (Original Portland Cement)와 PBFC (Portland Blast Furnace Slag Cement)를 이용한 실내배합시험 결과, DSM 시험시공, 그리고 계측을 포함한 본 시공 결과를 분석하였으며, 이 결과는 향후 비슷한 지반에서의 DSM적용 시 참고자료로 사용될 수 있을 것으로 판단된다.
\end{abstract}

Key Words : DSM, Deep Soil Mixing, Deep Excavation

\section{Introduction}

\subsection{Project Description}

The dual box ten-lane, $5 \mathrm{~km}$ long Marina Coastal Expressway (MCE) will be the tenth expressway in Singapore as shown in Fig.1. Meanwhile, the study site consists of $800 \mathrm{~m}$ of twin-cell box vehicular tunnel structure.

\subsection{DSM Application in this study}

For the twin-cell box vehicular tunnel structure, the temporary retaining structure (Tubular pipe pile + Strut) were planed including DSM (Deep Soil Mixing) with drilling length of $12 \sim 14 \mathrm{~m}$, improving length of $8 \sim 20 \mathrm{~m}$ and 2-shafts of $\Phi=1300 \mathrm{~mm}$. DSM applications such as soil properties of original ground, lab mixing test results, field trial test results, main DSM installation results including field monitoring measurements, coring for verification of DSM column to find out effectiveness of improvement and compliance with the requirements specified by Land Transport Authority-LTA (unconfined compressive strength, qu of $0.8 \mathrm{MPa}$, Elastic Modulus, E of $140 \mathrm{MPa}$, TCR of $85 \%$ ) were explained in this study

"Corresponding Author : Youn-Chul Chun(omma@samsung.com) 


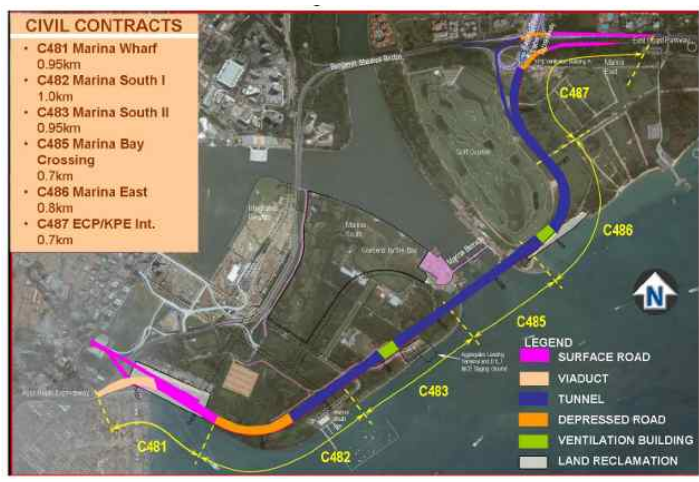

[Fig. 1] Plan for Marina Coastal Expressway

\section{DSM Method}

\subsection{Introduction}

The DSM Method is a kind of in-situ soil treatment and improvement technology, whereby to be used in downtown with the advantage of lower noise and vibration as a higher economical and productive method than other's.

The ground is blended with cementatious and/or other materials to form a vertical stiff column in the ground. These are injected through hollow, rotated mixing shafts tipped with some types of cutting tool.

In this technique, physical and chemical reactions between cement, clay minerals, and water including hydration, pozzolanic reaction (cementation), ion exchange, flocculation, precipitation, oxidation, and carbonation are allowed to take place deep below the ground to produce a high-strength product quickly which will continue to strengthen with time and lower permeability, and lower compressibility than the native ground (Bruce 2003).

The deep mixing methods have been employed in a various practice so far as shown in Fig. 2.

\subsection{Construction}

DSM equipment includes mixing shaft, mixing blade, mixing shaft holder, base machine, cement silo, mixing plant, grout pump and control room etc. as shown in Fig. 3. Typical DSM machine for 2-shafts and 4-shafts are shown in Fig. 4.

A column of treated soil is usually installed as a certain of manner, that is, during the penetration of the mixing shaft to the desired depth of improvement the mixing blades at the bottom end of the mixing shafts cut and disturb the soft soil to reduce the strength of the original soil. Then the shaft can penetrate into the soft ground by its own weight. At the same time, the stabilizing binder in a slurry form is to be injected into the soft soil and the mixing blades rotate in the horizontal plane and mix the soft soil with the binder.
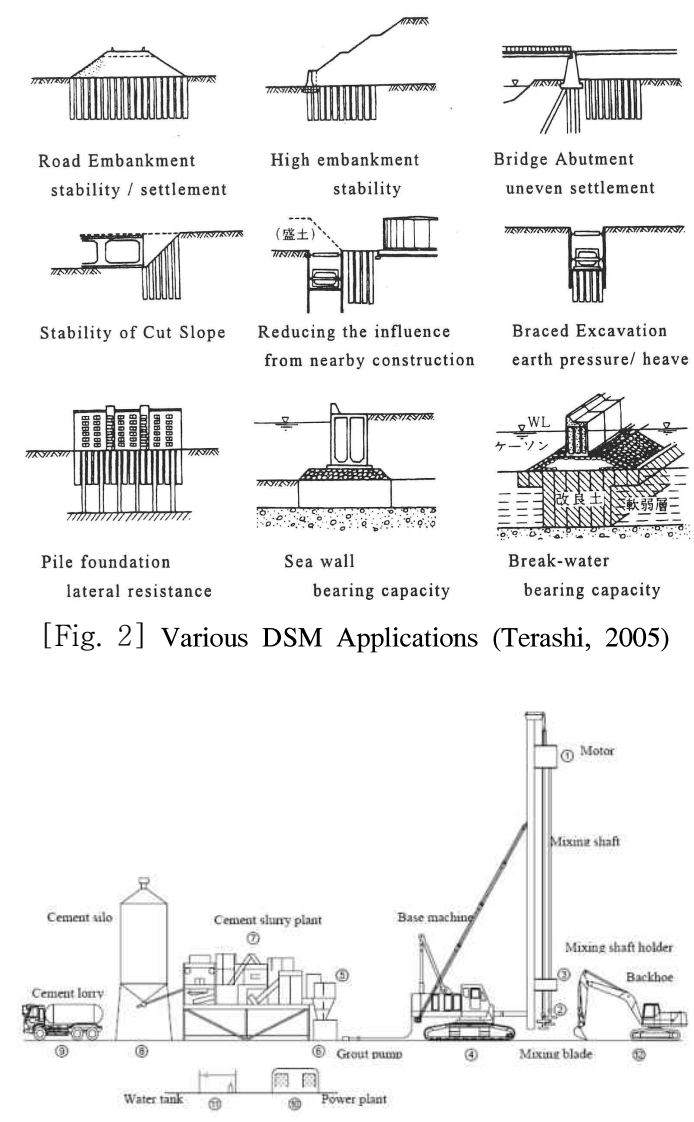

[Fig. 3] Standard DSM equipments (CDIT,2002)

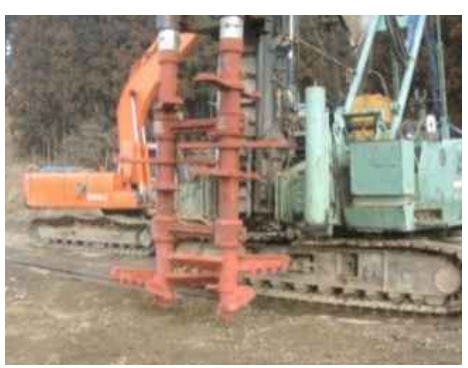

(a) 2 shafts 


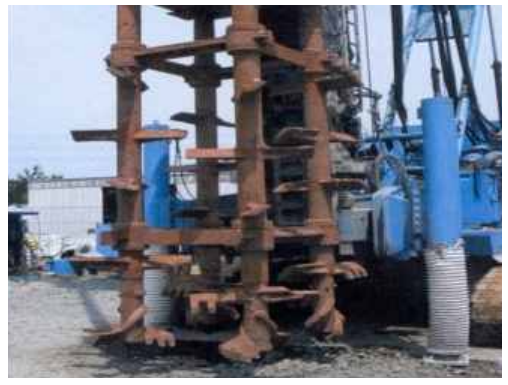

(b) 4 shafts

[Fig. 4] Blade and Bits for DSM Machine

\subsection{Lab mixing test}

Laboratory mixing tests should be conducted to determine a suitable type of stabilizing binder and a suitable quantity of the binder to ensure the design strength of the column in-situ. OPC(Original Portland Cement) or PBFC(Portland Blast Furnace Slag Cement) are usually used as a stabilizing binder in DSM. Procedure for lab mixing tests is based on JGS(Japanese Geotechnical Society) 0821. Laboratory strength is influenced by many factors, such as method to mold a specimen, the curing condition and testing conditions. To avoid these unexpected influence, it is recommended to follow the standardized laboratory mold test procedure such as JGS 0821 etc.

\subsection{Field trial test}

Because of the uncertainty regarding the applicability of the column characteristics determined in the laboratory, it is advisable to conduct the field trial test at the ground in or adjacent to the construction site before the main installation work, in order to confirm the favorable execution at a specific site. In the test, all the monitoring such as amount of stabilizing binder, rotation speed of mixing blade and penetration and retrieval speeds of shafts are to be calibrated. Also, the field trial test can be useful to confirm that designed mixing condition is adequate as the strength of the treated soil is measured after the trial test.

\subsection{QA/QC (Quality Assurance/Quality Control)}

To ensure the proper quality of stabilized column, quality control and quality assurance are required before, during and after construction. The sequence of the control for DSM quality mainly consists of laboratory mixing tests, quality control during construction and post construction quality verification through the inspection boring and pile head inspection. During construction, amount of stabilizing binder, rotation speeds of the mixing blade, penetration and retrieval speeds of the shaft are usually monitored at the interval of $1 \mathrm{~m}$ shaft movement. These data are displayed in the operation room for the operator to adjust the installation procedure to ensure the quality.

After installation operation, the quality of the in-situ stabilized columns should be verified before the construction of the upper structure in order to confirm the design quality, such as strength, permeability or dimension. Usually UCST (Unconfined compressive strength test) on the stabilized column are conducted for quality verification at curing time of 28 days, in which stabilized specimens are sampled from the construction site. The number of inspection borings is dependent upon the volume of the improved ground. In the inspection boring on the stabilized column, DSM samples are taken throughout the full depth in order to verify the continuity of the stabilized column like total core recovery (TCR).

\section{Application}

\subsection{Soil properties}

Soil layers in this study site consist of fill, KF (Kallang Formation) and OA (Old Alluvium). Kallang Formation is generally loose or soft in consistency with variable composition of recent deposits, and consists of UMC (Upper Marine Clay), LMC (Lower Marine Clay), F1(Fluvial Sand) and F2 (Fluvial Clay), Estuarine Clay etc. Soil layers to be improved by DSM are UMC, F2, and LMC below fill layer.

The soil properties in this study site are shown in Table 1. As in, the fill layer has average water content of $20 \%$ with average $\mathrm{N}$-value of 5 and belongs to $\mathrm{CL} \sim \mathrm{CV}$. UMC contains mostly silty clay with average water content of $65 \%$ and belongs to $\mathrm{CH} \sim \mathrm{CV}$. F2 layer is stiff or very stiff silty clay with average water content of $30 \%$ and belongs to $\mathrm{CL} \sim \mathrm{CV}$. LMC layer is soft or stiff silty 
clay with average water content of $50 \%$ and belongs to CI $\sim \mathrm{CE}$

[Table 1] Soil properties in this study site

\begin{tabular}{|c|c|c|c|c|}
\hline Layer & $\mathrm{N}_{\text {aveg }}$ & $\begin{array}{c}\mathrm{yt} \\
\left(\mathrm{kN} / \mathrm{m}^{3}\right)\end{array}$ & $\begin{array}{c}\text { Average } \\
\text { Water } \\
\text { content(\%) }\end{array}$ & $\begin{array}{c}\text { Classification } \\
(\text { Head 1992) }\end{array}$ \\
\hline Fill & 5 & 20.5 & 20 & $\mathrm{CH}$ \\
\hline UMC & - & 16.0 & 65 & $\mathrm{CH} \sim \mathrm{MH}$ \\
\hline F2 & 10 & 20.0 & 30 & $\mathrm{CL} \sim \mathrm{CV}$ \\
\hline LMC & - & 17.0 & 50 & $\mathrm{CH} \sim \mathrm{CV}$ \\
\hline Layer & $\begin{array}{c}\text { Void } \\
\text { Ratio }\end{array}$ & $\begin{array}{c}\text { Comp-r } \\
\text { ession } \\
\text { Index }\end{array}$ & O.C.R & $\begin{array}{c}\text { Shear } \\
\text { Strength } \\
(\mathrm{kPa})\end{array}$ \\
\hline Fill & & & 0.4 & 28 \\
\hline UMC & 2.0 & 0.9 & $10+1.2(\mathrm{z}-10)$ \\
\hline F2 & & 0.25 & & $20+1.5(\mathrm{z}-10)$ \\
\hline LMC & 1.4 & 0.6 & 0.6 & $20+1.5(\mathrm{z}-10)$ \\
\hline
\end{tabular}

\subsection{Lab mixing tests}

The lab mixing tests in 2 types of cement, OPC(Original Portland Cement) and PBFC(Portland Blast Furnace Slag Cement) with cement amount of $220 \sim 250 \mathrm{~kg} / \mathrm{m} 3$, w/c ( water cement ratio) of $0.8 \sim 1.2$ with seawater, and curing time of 7 50days, was performed by JGS 0821 to decide a proper cement amount and w/c including reviewing of soil properties of UMC, F2, LMC layer as shown in Table 2.

[Table 2] Plan for lab mixing tests

\begin{tabular}{|c|c|c|}
\hline Items & Quantity & Remarks \\
\hline $\begin{array}{c}\text { Soil } \\
\text { Properties } \\
\text { Test }\end{array}$ & 3 sets & $\begin{array}{l}\text { Particle size } \\
\text { and PL, } \omega_{\mathrm{n}}, \mathrm{G}_{\mathrm{s}}, \text { chloride } \\
\text { content, } \mathrm{pH}\end{array}$ \\
\hline $\begin{array}{l}\text { Mixing } \\
\text { Test }\end{array}$ & 35 batch & $\begin{array}{l}\text { 1) Binder type : OPC,PBFC } \\
\text { 2) Cement content( } 2 \text { case }) \text { : } \\
220 \mathrm{kgf} / \mathrm{m}^{3}, 250 \mathrm{kgf} / \mathrm{m}^{3} \\
3) \quad \mathrm{w} / \mathrm{c} \text { ratio(3 case) : } \\
0.8,1.0,1.2 \text { (only } \mathrm{F} 2 \text { layer) with } \\
\text { seawater }\end{array}$ \\
\hline UCST & $\begin{array}{l}315 \text { times } \\
(35 \times 3 \times 3)\end{array}$ & $\begin{array}{l}\text { 1) Curing time ( } 3 \text { case) : } \\
7,28,50 \text { days }\end{array}$ \\
\hline
\end{tabular}

Prior to lab mixing test, physical test was performed to review soil properties as shown in Table 3. All samples belong to silty clay.

It shows that water content of $67 \%$ with LL (liquid limit) of $75 \%$ in UMC, water content of $34 \%$ with LL of $49 \%$ in F2 and water content of $50 \%$ with LL of $62 \%$ in LMC. Head (1992) suggested plasticity chart as shown in Fig. 5 and UMC belongs to $\mathrm{CV}, \mathrm{F} 2$ to $\mathrm{CI}$ and LMC to CH. $\mathrm{pH}$ value for original soil have range of $7.9 \sim 8.5$ but treated soil have 12.5 13.0 respectively.

[Table 3] Summary of soil properties

\begin{tabular}{|c|c|c|c|c|c|}
\hline \multicolumn{3}{|c|}{ Soil Layer } & UMC & F2 & LMC \\
\hline Water & Content & $\%$ & 67 & 34 & 50 \\
\hline \multicolumn{2}{|c|}{ Wet Unit Weight } & $\mathrm{kN} / \mathrm{m}^{3}$ & 16.2 & 19.2 & 17.3 \\
\hline \multirow{3}{*}{$\begin{array}{l}\text { Atterberg } \\
\text { Limits }\end{array}$} & LL & $\%$ & 75 & 49 & 62 \\
\hline & $\mathrm{PL}$ & $\%$ & 26 & 18 & 21 \\
\hline & PI & - & 49 & 31 & 41 \\
\hline \multirow{4}{*}{$\begin{array}{c}\text { Particle } \\
\text { Size } \\
\text { Analysis }\end{array}$} & Gravel & $\%$ & 0 & 0 & 0 \\
\hline & Sand & $\%$ & 0 & 1 & 0 \\
\hline & Silt & $\%$ & 50 & 52 & 50 \\
\hline & Clay & $\%$ & 50 & 47 & 50 \\
\hline \multicolumn{2}{|c|}{ Specific Gravity } & - & 2.59 & 2.67 & 2.67 \\
\hline \multicolumn{2}{|c|}{ Chloride Content } & $\%$ & 0.59 & 0.43 & 0.28 \\
\hline \multirow{2}{*}{\multicolumn{2}{|c|}{$\mathrm{pH}$ (original) value }} & - & 8.4 & 7.9 & 8.5 \\
\hline & & - & 12.5 & 13 & 12.5 \\
\hline
\end{tabular}

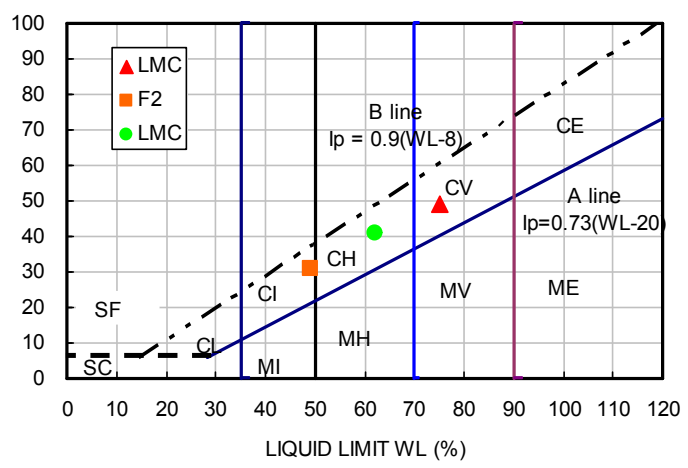

[Fig. 5] Plasticity chart, Head (1992)

As shown in Fig. 6, the results meet all requirements except OPC(Original Portland Cement) results at curing time of 7 days. And unconfined compressive strength and elastic modulus mostly increase with increasing in time and cement amount and decrease with increasing in w/c. But some part didn't follow this trend and these are mainly shown in F2 and little in UMC. And the water content of treated soil may be lower enough than that of having proper mixing. And comparing between OPC and $\mathrm{PBFC}$, it is obvious that the strength by $\mathrm{PBFC}$ is higher than by OPC. 


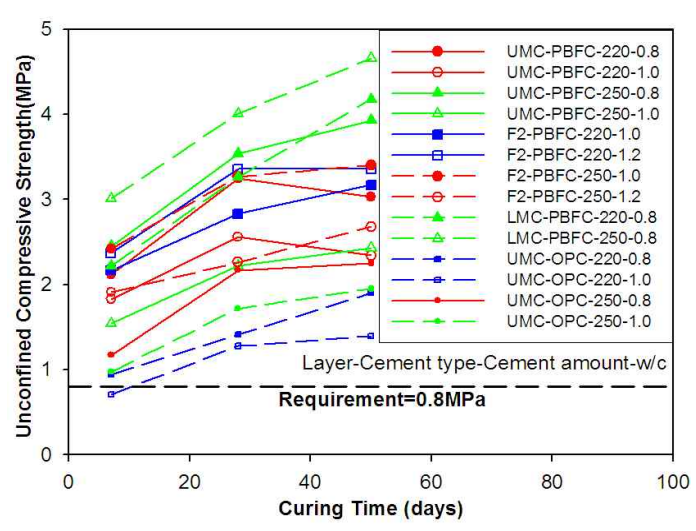

(a) Correlation between UCS and curing time

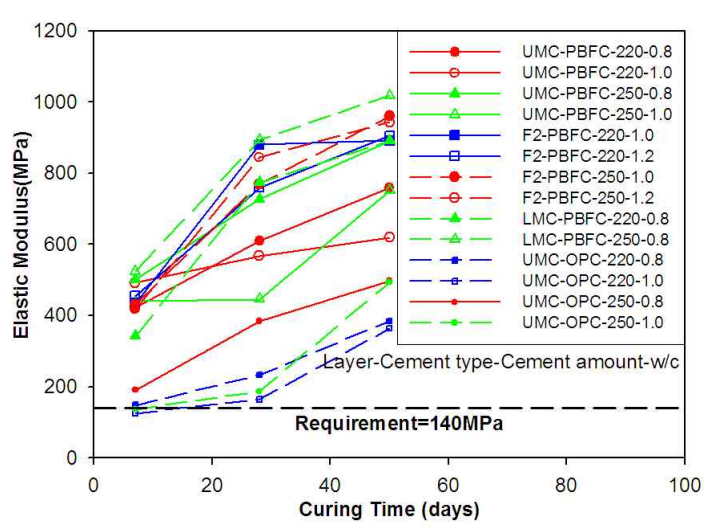

(b) Correlation between $\mathrm{E}$ and curing time

[Fig. 6] Lab mixing tests results

Correlation between UCS and E in a range of 150 400qu was suggested by Tan (2002) as shown in Fig. 7 (a), that is, tested in cement contents of $10 \sim 30 \%$, water content (original clay) of $90 \sim 150 \%$ and curing time of $1 \sim 161$ days respectively and herein this project is similar to the previous results of $150 \sim 400 \mathrm{qu}(\mathrm{Tan}, 2002)$ as shown Fig. 7(b).

As shown above, some part of treated soil was not properly mixed. These are detected in F2 and little in UMC. However, the results meet requirements with PBFC. So cement amount in a range of $180 \sim 220 \mathrm{~kg} / \mathrm{m} 3$, $\mathrm{w} / \mathrm{c}$ in a range of $80 \sim 100 \%$ were planed for field trial test. It is clear that role of lab mixing test is to determine a suitable type of stabilizing binder and a suitable quantity of the binder for field trial test and to find out effectiveness of improvement.

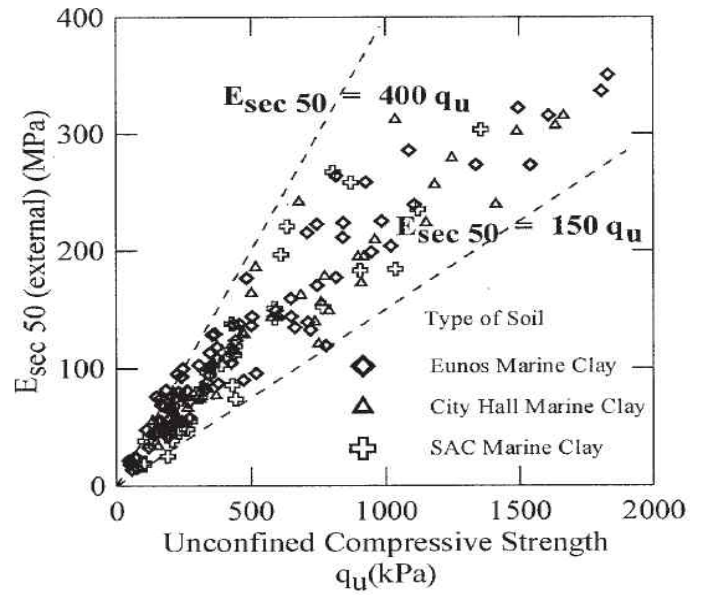

(a) Previous study by Tan in Singapore (Tan, 2002)

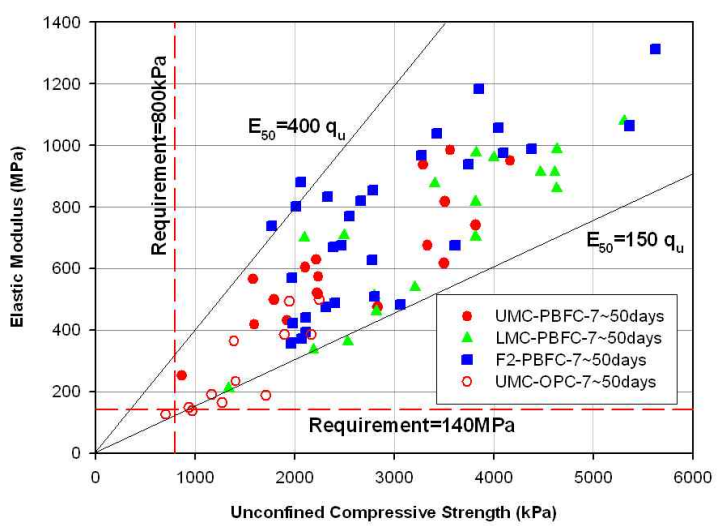

(b) Results in this study

[Fig. 7] Correlation between UCS and E

\subsection{Field trial test}

The results of lab mixing test have some of uncertainty, so it needs to check through the field trial test. The location of the test is next to the main installation area as shown on Jeong and Lim (2009).

In the past illustrations, applications for DSM was applied in 4 shafts of $\Phi=1000 \mathrm{~mm}$ with OPC, but in this study 2 shafts of $\Phi=1300 \mathrm{~mm}$ with $\mathrm{PBFC}$ was planed in a brand new type machine to decide proper cement amount and $\mathrm{w} / \mathrm{c}$ for main installation. Cement amount is in a range of $180 \sim 220 \mathrm{~kg} / \mathrm{m} 3$ with w/c of $80 \sim 100 \%$ as shown in Fig. 8 and Table 4. 


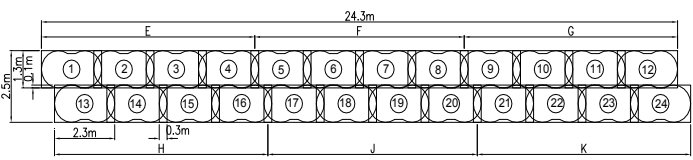

[Fig. 8] Plan view of trial test for $2 \operatorname{shafts}(\varphi=1,300 \mathrm{~mm})$

[Table 4] Plan for field trial test (PBFC)

\begin{tabular}{|c|c|c|c|c|c|}
\hline \multicolumn{2}{|c|}{ Bore No. } & \multirow{3}{*}{$\begin{array}{c}\text { DSM Type } \\
\begin{array}{c}\text { 2shafts } \\
(\Phi=1300 \mathrm{~mm})\end{array}\end{array}$} & \multirow{2}{*}{$\begin{array}{c}\text { Cement } \\
\text { Amount } \\
\left(\mathrm{kg} / \mathrm{m}^{3}\right)\end{array}$} & \multirow{2}{*}{$\begin{array}{c}\begin{array}{c}\text { Treated } \\
\text { Layer }\end{array} \\
16 \mathrm{~m}\end{array}$} & \multirow{2}{*}{$\begin{array}{l}\mathrm{W} / \mathrm{C} \\
(\%) \\
100\end{array}$} \\
\hline E & $1 \sim 4$ & & & & \\
\hline $\mathrm{F}$ & $5 \sim 8$ & & 200 & $10 \mathrm{~m}$ & 100 \\
\hline G & $9 \sim 12$ & & 220 & $10 \mathrm{~m}$ & 80 \\
\hline $\mathrm{H}$ & $12 \sim 16$ & & 200 & $10 \mathrm{~m}$ & 80 \\
\hline $\mathrm{J}$ & $16 \sim 20$ & & 180 & $10 \mathrm{~m}$ & 100 \\
\hline K & $20 \sim 24$ & & 180 & $10 \mathrm{~m}$ & 120 \\
\hline
\end{tabular}

As shown in Fig. 9 and Table 5, average ampere at penetration is in a range of $248.6 \mathrm{~A} \sim 380.2 \mathrm{~A}$ and average installation time is $92.5 \sim 136.6$ minutes. But concerning to F2 layer, ampere is similar to those of fill layer as shown in Fig. 9 due to higher stiffness than others clay layers (UMC, LMC).

Samples were cored and tested. The results of UCS, E, TCR are shown in Fig. 10 at curing time of 7 51days. All tested samples meet requirements of $0.8 \mathrm{MPa}$ for UCS and $140 \mathrm{MPa}$ for $\mathrm{E}$ at curing time of 28days or more.

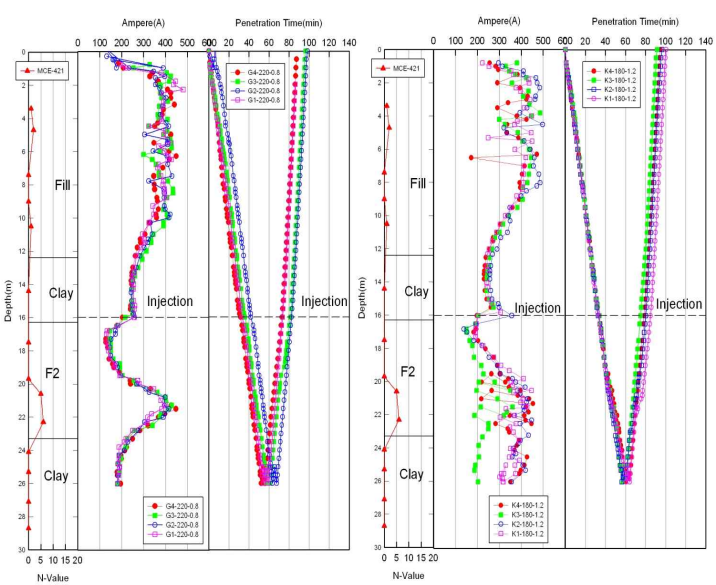

[Fig. 9] Ampere at penetration and Total Installation Time for G Spot and K Spot.
[Table 5] Trial test results (ampere and installation time)

\begin{tabular}{|c|c|c|c|}
\hline \multicolumn{2}{|c|}{ Bore } & $\begin{array}{c}\text { Average Ampere (A) } \\
\text { at Penetration }\end{array}$ & $\begin{array}{l}\text { Installation } \\
\text { Time (min) }\end{array}$ \\
\hline E & $1 \sim 4$ & 248.6 & 95.8 \\
\hline $\mathrm{F}$ & $5 \sim 8$ & 293.7 & 102.3 \\
\hline G & $9 \sim 12$ & 299.1 & 92.5 \\
\hline $\mathrm{H}$ & $12 \sim 16$ & 380.2 & 136.6 \\
\hline J & $16 \sim 20$ & 357.3 & 119.7 \\
\hline K & 20 24 & 331.8 & 95.9 \\
\hline
\end{tabular}

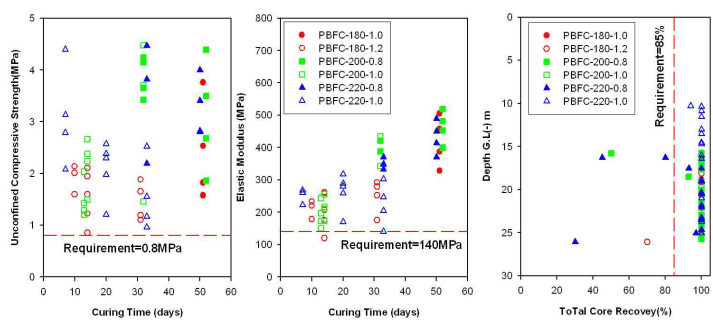

[Fig. 10] Distribution of UCS, E with curing time (days) and TCR with depth (m) for field trial test.

Almost all samples comply with requirement of $85 \%$ TCR and average TCR in each investigated hole is complied with $85 \%$ TCR. As shown above, based on average ampere at penetration and average installation time, cement amount of $200 \mathrm{~kg} / \mathrm{m} 3$ with $\mathrm{w} / \mathrm{c}=1.0$ and $220 \mathrm{~kg} / \mathrm{m} 3$ with $\mathrm{w} / \mathrm{c}=0.8$ or 1.0 are proper for main installation. When comparing between them with UCS, E and TCR, the results of $200 \mathrm{~kg} / \mathrm{m} 3$ with $\mathrm{w} / \mathrm{c}=1.0$ and $\mathrm{w} / \mathrm{c}=1.2$ show better than those of $220 \mathrm{~kg} / \mathrm{m} 3$ with $\mathrm{w} / \mathrm{c}=0.8$ or 1.0 as shown in Fig. 10. Therefore, in a main construction, cement amount of $200 \mathrm{~kg} / \mathrm{m} 3$ with $\mathrm{w} / \mathrm{c}=1.0$ or $\mathrm{w} / \mathrm{c}=1.2$ are selected.

When comparing between lab mixing test results and field trial test result for the same cement amount and $w / c$ like $220 \mathrm{~kg} / \mathrm{m} 3, \mathrm{w} / \mathrm{c}=0.8 \sim 1.0$, it shows that field trial test results lay in a half of lab results and can draw correlation between UCS and E, E=75 200qu with half value of lab mixing test results $(E=150 \sim 400 q u)$ for this study as shown in Fig. 11. 


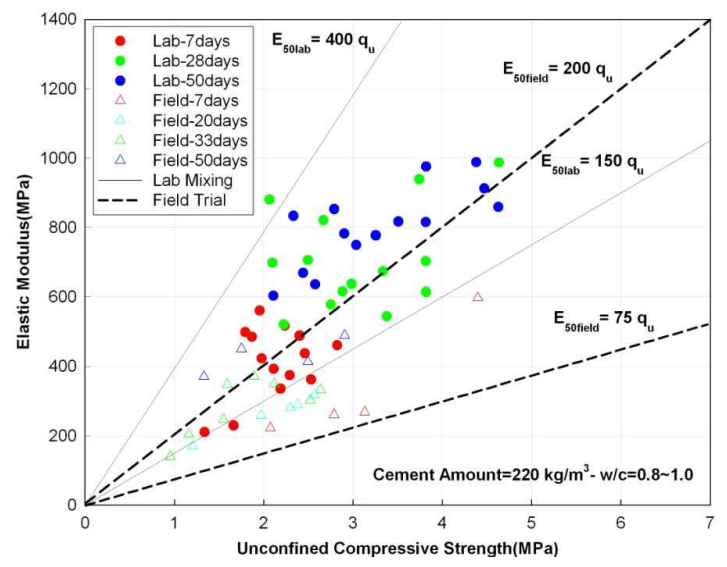

[Fig. 11] Correlation between lab and field test results

\subsection{Main installation}

DSM (Deep Soil Mixing) with drilling length of $12 \sim 14 \mathrm{~m}$ and improving length of $8 \sim 20 \mathrm{~m}$ with 2-shafts of $\Phi=1300 \mathrm{~mm}$ was adopted as a kind of the underground strut system in order to prevent the excessive wall deflection which can be caused by the excavation in soft ground as shown in Fig. 12.

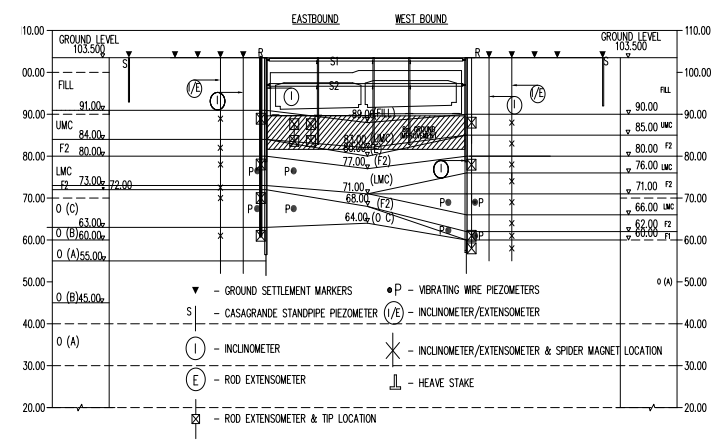

[Fig. 12] Typical Section in TERS (Temporary Earth Retaining System) monitoring.

Unconfined compressive strength, qu of cored samples from main installation are shown in Fig. 13. Unconfined compressive strength and elastic modulus are complied with requirements stipulated by client and average TCR in each investigated hole is complied with $85 \%$ TCR.
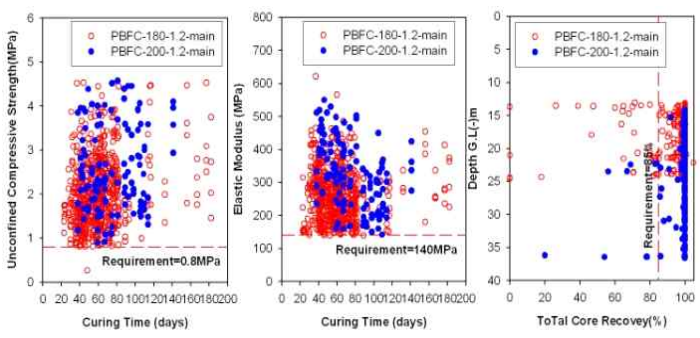

[Fig. 13] Distribution of UCS, E with curing time (days) and TCR with depth (m) for main installation.

When comparing between lab mixing test results and main installation results, it shows that main installation results lay in a half of lab results and can draw correlation between UCS and E, E=75 200qu with half value of lab mixing test results $(E=150 \sim 400 q u)$ for this study as shown in Fig. 14.

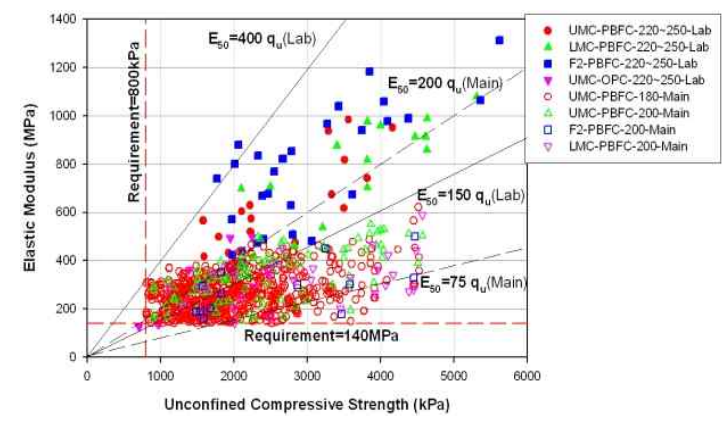

[Fig. 14] Correlation between lab and main installation.

The tunnel box is constructed by cut and cover method with strutting system and DSM.

The maximum allowable lateral movement of the temporary retaining wall is within $0.5 \%$ of excavated depth in a range of $60.0 \sim 77.5 \mathrm{~mm}$. To compare with predicted and measured wall deflection, monitoring measurements are performed during excavation after DSM cured.

Predicted and measured maximum horizontal displacements in eastbound section are $57.83 \mathrm{~mm}$ and $19.16 \mathrm{~mm}$ while $39.09 \mathrm{~mm}$ and $30.93 \mathrm{~mm}$ in the westbound section as shown in Fig. 15. Also, heave at the stage of final excavation is limited to $10.4 \mathrm{~mm}$. This is the one evidence of the performance of DSM layer as a kind of underground strut system. 

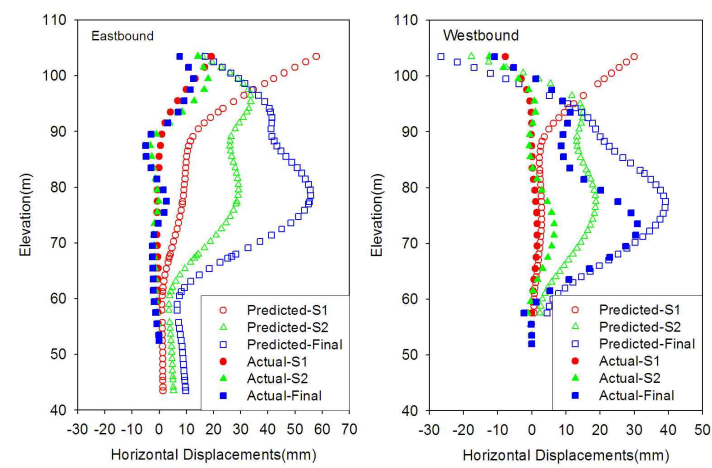

[Fig. 15] Comparison between predicted and measured horizontal displacements.

\section{Conclusion}

This paper is to show DSM(Deep Soil Mixing) application of lab mixing test, field trial test and main installation for deep excavation.

1) Lab mixing test results meet all requirement of 0.8MPa for UCS(Unconfined Compressive Strength, qu) and 140MPa for E(Elastic Modulus) at curing time of 28days. It is clear that role of lab mixing test is to determine a suitable type of stabilizing binder and a suitable quantity of the binder for field trial test and to find out effectiveness of improvement.

2) Correlation between UCS(Unconfined Compressive Strength, qu) and E(Elastic Modulus) in Lab-mixing test is similar to the previous study (Tan, 2002), and $\mathrm{E}=150 \sim 400 \mathrm{qu}$.

3) In a main installation work, the test results of UCS(Unconfined Compressive Strength, qu) and E(Elastic Modulus) installed with 2 shafts of $\Phi$ $=1300 \mathrm{~mm}$ at curing time of 28 days comply with requirement of $0.8 \mathrm{MPa}$ for $\mathrm{UCS}$ (Unconfined Compressive Strength, qu) and $140 \mathrm{MPa}$ for E(Elastic Modulus) and correlation between UCS(Unconfined Compressive Strength, qu) and $\mathrm{E}$ (Elastic Modulus) shows $\mathrm{E}=75 \sim 200 \mathrm{qu}$ in a half value of lab mixing tests.

4) Past DSM applications in Singapore was to be 4-shafts of $\Phi=1000 \mathrm{~mm}$ with OPC(Original Portland Cement). But recently 2 -shafts of $\Phi=1300 \mathrm{~mm}$ with
PBFC(Portland Blast Furnace Slag Cement) are adopted for temporary works for more economical and higher quality trend.

5) Comparison between predicted and measured horizontal displacements in TERS(Temporary Earth Retaining System) presented that the measured displacements are quite limited. It is the one of evidence of the performance of DSM layer as a kind of underground strut system.

6) For better understandings of properties of DSM improved Singapore clay, it is recommended to get more illustrations to analyze characteristics of DSM in Singapore clay.

\section{References}

[1] Bruce D. A., Bruce M. E. C,. "The practitioner's Guide to Deep Mixing." Grouting and Ground Treatment; Proceedings of the 3rd International Conference, ASCE Geotechnical Special Publication No. 120New Orleans, 2003.

[2] CDIT Japan, "The Deep Mixing Method Principle, Design and Construction", pp 93 110, 2002.

[3] Head, "Manual of Soil Laboratory Testing, Volume 1” pp 69 70, 1992.

[4] Japanese Geotechnical Society Standard, "Practice for Making and Curing Stabilized Soil Specimens Without Compaction (JGS 0821)", 2000.

[5] Jeong G.H and Lim S.S, "Case study of DSM trial tests for MCE project (C-486) in Singapore"2nd world Roads Conference, 2009.

[6] LTA (Land Transport Authority, "Geotechnical Interpretative Baseline Report”, Mar 2008.

[7] Tan T.S, "Properties of Singapore Marine Clays Improved by Cement Mixing",Geotechnical Testing Journal, 2002.

[8] Terashi,M, "Design of Deep Mixing in Infrastructure Applications", International Conference on Deep Mixing Best Practice and Recent Advance, 2005.

\section{Abbreviation}

\section{E : Elastic Modulus}

DSM : Deep Soil Mixing 
F1 : Fluvial Sand

F2 : Fluvial Clay

JGS : Japanese Geotechnical Society

KF : Kallang Formation

LL : Liquid Limit

LMC : Lower Marine Clay

LTA : Land Transport Authority

MCE : Marina Coastal Expressway

OA : Old Alluvium

OPC : Original Portland Cement

PBFC : Portland Blast Furnace Slag Cement

QA/QC : Quality Assurance/Quality Control

TCR : Total Recovery Ratio

TERS : Temporary Earth Retaining System

UCS(T) : Unconfined Compressive Strength Test

UMC : Upper Marine Clay

\section{Youn-Chul Chun [Regular member]}

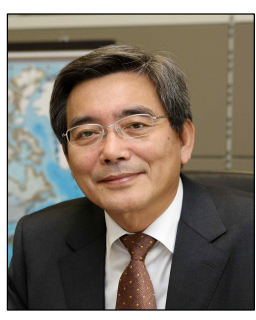

$<$ Research Interests $>$

Soft Ground
- Feb. 1981 : Seoul National Univ., Civil Engineerig, BS

- Sep. 2006 : Busan National Univ., Civil Engineering, MS

- Mar. $2007 \sim$ current : Kyonggi Univ. Civil Engineering Ph.D Candidate Sanhak LtD., Engineer

- Jan. $20101 \sim$ current : Samsung C\&T Corp. Vice President 